11 For example, see Willard's comparison of herself to Susan B. Anthony (Glimpses, 598).

12 Ruth Bordin, for example, concludes that Willard's "primary emotional ties" were all with women but "they seem not have been explicitly homosexual"; see Bordin, "Willard, Frances Elizabeth Caroline," American National Biography (New York: Oxford University Press, 2002). Yet Willard figures in Lillian Faderman, To Believe in Women: What Lesbians Have Done for America (Boston: Houghton Mifflin, 1999). See also Jean H. Baker, Sisters: The Lives of America's Suffragists (New York: Hill and Wang, 2006).

13 For Bucke's letters to Whitman about his chilly reception at the Smiths' in London, see Richard Maurice Bucke, Medical Mystic: Letters of Dr. Bucke to Walt Whitman and His Friends, ed. Artem Lozynsky (Detroit: Wayne University Press, 1977), 154-164. Whitman's parenthetical question to Bucke-"(have they dropt me?)"-is in Walt Whitman, The Correspondence, ed. Edwin Haviland Miller (New York: New York University Press, 1961-1969), 5:223.

\title{
LOS ANGELES, 1960: JOHN F. KENNEDY AND WHITMAN'S SHIP
}

\section{OF DEMOCRACY}

Walt Whitman had a long and meaningful relationship with the United States presidency. With brothers named George Washington, Thomas Jefferson, and Andrew Jackson Whitman, the poet seemed destined to grow up positioning his work in relation to both the office and the men who occupied it. From the bitter rhetoric of "The Eighteenth Presidency!" to the astonishing art of "When Lilacs Last in the Dooryard Bloom'd," Whitman paralleled his poetic achievement with the nation's highest office. It was with a combination of respect, frustration, and rivalry that he wrote of Americans, in the preface to the 1855 edition of Leaves of Grass, "Their Presidents shall not be their common referee so much as their poets shall."

Presidents and presidential candidates have had their own history with Whitman. James Garfield and Grover Cleveland met Whitman and admired Leaves of Grass. ${ }^{1}$ Teddy Roosevelt described Whitman as a Dante of the Bowery and lamented that more Americans did not know his work. ${ }^{2}$ The five-time Socialist presidential candidate Eugene Debs had deep affection for Leaves of Grass and regularly corresponded with Horace Traubel and the Walt Whitman Fellowship. Modern presidents have been particularly fond of invoking "I Hear America Singing." Lyndon Johnson quoted from the poem when he introduced a jobs bill to Congress in $1967 .^{3}$ Ronald Reagan referred to the poem when speaking to the Conservative Political Action Committee about his 1984 landslide victory. ${ }^{4}$ Richard Nixon quoted from "Song of the Broad-Axe" in a speech about community development, and the elder George Bush adapted a line from "Starting from Paumanok" in a speech to religious broadcasters. ${ }^{5}$

A search of the American Presidency Project (an online archive hosted by the University of California, Santa Barbara) reveals that Bill Clinton quoted Whitman seven times during his presidency. As Ed Folsom has written, how- 
ever, when it comes to poetry, the president is perhaps best known for the copy of Leaves of Grass he gave to the White House intern Monica Lewinsky. While George W. Bush did not personally align himself with Whitman, his decision to invade Iraq became entangled in conflicting opinions about the poet's vision. New York Times columnist David Brooks cited lines from Democratic Vistas to justify the President's nation building. But when First Lady Laura Bush organized a White House celebration of the work of Whitman, Emily Dickinson, and Langston Hughes, poets around the country planned to use the event to protest the Iraq war. ${ }^{6}$

Although we most frequently associate him with Robert Frost, John F. Kennedy had a brief, but telling, public relationship with Whitman's poems. In 1960, Kennedy famously held the last night of the Democratic National Convention in the Los Angeles Coliseum, thus creating a massive open-aired event that brought his acceptance speech to the people. It was an audacious, highly-theatrical move (one that would later inspire Barack Obama). Kennedy was not only a charismatic speaker, but he had deep roots in the Los Angeles entertainment community. His father, Joe, had started RKO pictures in 1929, and his sister Pat was married to the actor Peter Lawford, an original member of the Rat Pack. Fitting both the candidate and the setting, the convention had given a large cast of actors, actresses, singers, and dancers the task of entertaining the delegates and spectators before the convention's official business began each evening.

The organizers had announced that on the convention's final night Marlon Brando would read from Whitman's poetry, but Brando eventually withdrew in order to prepare for his upcoming role in Mutiny on the Bounty. ${ }^{7}$ Edward G. Robinson took Brando's place in reading a section from "Thou Mother With Thy Equal Brood" in front of the 100,000 people gathered in the Coliseum. A well-known Hollywood activist who had been called before the House UnAmerican Activities Committee, Robinson had appeared in such films as Little Caesar, Double Indemnity, and The Ten Commandments. His participation in the convention could be read as a sign of liberal fortitude and defiance.

In contrast to the other performances, Robinson's reading made it onto the live television broadcast. After Kennedy, Lyndon Johnson, and scores of other dignitaries had made their way to the speaker's platform (Kennedy had wanted every Democratic governor and state senator to be seated behind him as a sign of party unity), Steve Allen introduced the poem to the gathered audience:

Ladies and Gentlemen, your attention please. More than seventy-five years ago, the beloved poet Walt Whitman wrote the lines that you are about to hear. They are remarkable not only for their beauty and patriotism but for the fact that they might well have been written for this occasion this afternoon. To read them, I bring you now a great actor, a gentleman who will be accompanied by the orchestra under the baton of our musical director Johnny Green, Mr. Edward G. Robinson. ${ }^{8}$

On the CBS broadcast, Walter Cronkite talked through Allen's introduction, so only the last sentence highlighting Robinson and Green would have been 
audible to the television audience. Whitman's poem seems almost orphaned in the process, the words part of the moment's pageantry rather than the contribution of a prescient American poet.

And pageantry there was. Holding a single sheet of paper, Robinson eloquently declaimed Whitman's words with the music of "America the Beautiful" softly rising in the background. In an effort presumably to make the lines more accessible, someone had modernized the language and eliminated Whitman's reference to the necessary subordination of other continents and countries:

Sail, sail your best, ship of Democracy,

Of value is your freight, it is not the Present only,

The Past is also stored in you,

You hold not the venture of yourself alone, not of the Western continent alone,

Earth's entire floats on your keel $\mathrm{O}$ ship, is steadied by your spars,

With you Time voyages in trust, the antecedent nations sink or swim with you,

With all their ancient struggles, martyrs, heroes, epics, wars, you bear the other continents, Theirs, theirs as much as your's,

Steer then with good strong hand and wary eye $\mathrm{O}$ helmsman, you carry great companions. ${ }^{9}$

The crowd greeted the selection with sustained applause, but there was also significant confusion. Robinson moved off screen, and Allen reclaimed the podium. But the orchestra kept playing over Allen's remarks. Eventually Allen relented, the music got louder, and the politicians and crowd joined the choir in singing the first verse of "America, the Beautiful."

Whitman's poem served several objectives for the Kennedy campaign. In the course of the long afternoon and evening, it provided a meaningful transition between the hoopla of entertainment and the more serious business of Kennedy's accepting the Democratic Party's nomination. Whitman, and poetry itself, straddled both worlds, and as soon as the crowd had finished singing, Allen turned matters over to Florida Governor Leroy Collins who brought the session to order. Whitman represented high entertainment but also a kind of civic religion. Indeed, as soon as Collins pounded his gavel, a minister arose to deliver a long benediction that covered everything from the Puritan's forbearance to the world's travails. Performed by Robinson, accompanied by Green's orchestra, the poem functioned as a transition between entertainment, prayer, and a politics that was hard-knuckled, nationalistic, and visionary.

It is unclear how much thought went into the choice of "Thou Mother With Thy Equal Brood." With its opening image of mother America acknowledging each of her states, the poem would have skillfully addressed a party that needed to unify state delegations behind a single candidate. By including only the "Ship of Democracy" section, however, the program looked forward to the general election, focusing less on the convention floor than on the character of the party's candidate. The Democrats returned to the nautical/ ship of state imagery throughout the campaign. As Henry Fonda explained in a five minute commercial televised later that fall, Kennedy, like Franklin 
Roosevelt, was a man of the sea. He had served heroically in the navy and had saved a number of his crewmates' lives after their P-T boat was destroyed in the South Pacific. Still, too, Kennedy was a sailor, and images of his sailing off the coast of Cape Cod had been featured in Life Magazine. ${ }^{10}$ Whitman's poem imparted the message that the fate of American democracy - and the earth itself-depended on Kennedy's careful leadership. Whitman's optimism in the face of a grim reality fit the tone of Kennedy's campaign.

To those of us on the other side of his presidency, the invocation of Kennedy as heading the ship of state eerily recalls Whitman's most famous presidential connection, the image of Abraham Lincoln in "O Captain! My Captain!" From this perspective, Kennedy becomes not the FDR who battled physical ailments to inspire a troubled nation but a leader tragically cut down by an assassin. When Kennedy died on November 22, 1963, broadcasters turned to Whitman. Radio stations played readings of "O Captain! My Captain!" Television stations aired a commemorative program of Whitman's and Frost's poetry in which actors read passages from "When Lilacs Last in the Dooryard Bloom'd," "To a Foiled European Revolutionaire," and "Over the Carnage Rose Prophets." 11

Kennedy was fond of citing Emerson's comment that American history had always been divided between the party of memory and the party of hope. ${ }^{12}$ Democrats are the party of hope, he told an audience at a fundraising dinner at the Waldorf-Astoria, and that is why artists and writers so frequently find themselves at home with them. ${ }^{13}$ The men and women surrounding Kennedy found in Whitman a way to invoke the memory of that hope while also demonstrating its ability to persevere amid the coldest of realities.

The College of New Fersey

David Haven Blake

\section{NOTES}

1 See Frederick Hatch, "Presidents, United States," Walt Whitman: An Encyclopedia, eds. J.R. LeMaster and Donald D. Kummings (Garland: New York, 1998), 548.

2 Theodore Roosevelt, "Dante and the Bowery," History as Literature and Other Essays (Scribner's: New York, 1913), 220-221.

3 Lyndon Johnson, "Special Message to the Congress-To Earn a Living: The Right of Every American." (January 23, 1968), The American Presidency Project (www.presidency.ucsb.edu), ed. John T. Woolley and Gerhard Peters (University of California, Santa Barbara).

4 Ronald Reagan. "Remarks at the Annual Dinner of the Conservative Political Action Conference." (March 1, 1985), The American Presidency Project.

5 Richard Nixon, "Radio Address About the State of the Union Message on Community Development." (March 4, 1973); George Bush, "Remarks at the Annual Convention of the National Religious Broadcasters" (January 27, 1992), The American Presidency Project.

6 Ed Folsom, “'What a Filthy Presidentiad!': Clinton's Whitman, Bush's Whitman, and Whitman's America," Virginia Quarterly Review (Spring 2005), 96-113. 
7 Murray Schumach, "Democrats to Get Hollywood Help," New York Times (June 30, 1960), 22; Murray Schumach, "Amateurs Will Outnumber Stars at Democrats' Convention Show," New York Times (July 7, 1960), 11.

81960 Democratic National Convention, Los Angeles, California. (July 15, 1960). CBS Television broadcast. John F. Kennedy Library Foundation. All descriptions and quotations about the performance come from this broadcast. My thanks to Laurie Austin, Audiovisual Archivist at the John F. Kennedy Presidential Library and Museum.

9 The Deathbed edition version of the poem is more antiquated and confrontational:

Sail, sail thy best, ship of Democracy,

Of value is thy freight, 'tis not the Present only,

The Past is also stored in thee,

Thou holdest not the venture of thyself alone, not of the Western continent alone,

Earth's résumé entire floats on thy keel O ship, is steadied by thy spars,

With thee Time voyages in trust, the antecedent nations sink or swim with thee,

With all their ancient struggles, martyrs, heroes, epics, wars, thou bear'st the other continents,

Theirs, theirs as much as thine, the destination-port triumphant;

Steer then with good strong hand and wary eye O helmsman, thou carriest great companions,

Venerable priestly Asia sails this day with thee,

And royal feudal Europe sails with thee. (348)

10 Life had featured Kennedy sailing with his fiancé Jacqueline Beauvoir on its July 20, 1953, cover.

11 On the use of Whitman during the Kennedy funeral broadcasts, see P.V. Rizzo, "John F. Kennedy and Whitman," Walt Whitman Review 10 (June 1964), 42; see also Robert H. Woodward, "John F. Kennedy and Whitman: An Addendum." Walt Whitman Review 12 (June 1966), 44-45.

12 Ralph Waldo Emerson, "The Conservative," Essays and Lectures (Library of America: New York, 1983), 173.

13 John F. Kennedy, "Remarks at the New York Birthday Salute to the President." (May 23, 1963), The American Presidency Project. 